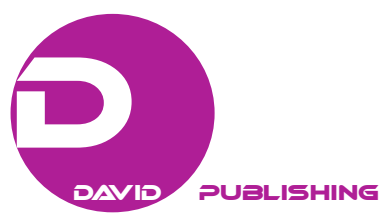

\title{
The Question Concerning Techno-Utopia
}

\author{
Szymon Wróbel \\ University of Warsaw, Warsaw, Poland
}

\begin{abstract}
The author, in this paper, asks the question, why is technology the key concept in shaping the utopian imagination. In previous times, starting from Thomas Morus, the foundation of utopian thinking was rather the state and social organization, not the means of production. Surprisingly, it appears that, without technological support, both social and political utopias are nothing. Technology gives credibility to the utopian project. Jules Verne or Edward Bellamy only gives credibility to what is otherwise incredible. What, then, is the utopian feature of Utopia as regards to technology? The author claims that Utopia reverses the methodological maxim, whereby conclusions about possibilities can be drawn only from the real. Utopia does the opposite: Everything that exists operates within the technological organization and its capabilities. After all, Herbert George Wells' time machine does not bring us to a politically-thought-out organization, benefiting everyone, but a sluggish race living in small groups and feeding on fruits. It is a humanity liberated from both work and thinking, humanity at its end, unemployed humanity. In the paper, the author, following the path laid by Martin Heidegger, Michel Foucault, Giorgio Agamben, and Bernard Stiegler, is trying to rethink the problematic "utopian perfection of technology” seeking universal automatism and generating a new organization of work.
\end{abstract}

Keywords: automatization, technology, techno-utopia, the future of work

\section{Opening Question}

Technological utopias appearing in literature and cinema are by no means uncommon. The tenet, however, is not to get fascinated with technical inventions that anticipated reality both in literature and on the screen, nor to talk about utopian literature as a vehicle for all human invention. Rather, the point is to determine in what relations these prophetic inventions remain with the social relations illustrated in the very same works and whether these social relations keep up with technological changes, or whether they constitute "conservative variables" or "conservative power" in the evolution of social forms.

The author, therefore, asks why it is technology that provides the abundance of material for reflection on utopia and why technology is the key concept in shaping the utopian imagination. In previous times, starting from Thomas More, the foundation of utopian thinking was rather the state and social organization, not the means of production (More, 1516/1967). Surprisingly, it appears that, without technological support, both social and political utopias are nothing. Technology gives credibility to the utopian project. The utopist is neither a prophet nor a bard. Jules Verne or Edward Bellamy only give credibility to what is otherwise incredible. What, then, is the utopian feature of utopia as regards to technology? Does technological utopia set upon the world in such a way that it appears a visible system of powers? Does the utopian experiment summon

Szymon Wróbel, Professor, Institute of Philosophy and Sociology of Polish Academy of Sciences, Faculty of Artes Liberales, University of Warsaw, Warsaw, Poland. 
and discover nature? Perhaps Utopia reverses the methodological maxim, whereby conclusions about possibilities can be drawn only from the real. Utopia does the opposite: Everything that exists operates within the technological organization and its capabilities.

This text will attempt to start a normative reflection, i.e., ask why, in futuristic thinking technology, is often perceived as a threat, not as an opportunity. Why do robots, machines, thinking machines, androids, or cyborgs-upon reaching a certain level of complexity—alienate themselves from humanity and eventually take over the human world by establishing a new non-human form of power? The author will talk here about technological anxiety, which results in a kind of poverty of technological imagination. The author is compelled to claim that in solving this problem, we first need to address our erroneous conception of technology and the erroneous way of understanding the relationship between the means of production and relations of production, between technology and socialization, technical resources, and communication resources, "engineers' technology" understood as the domain of "machine" and "social technics" understood as the "art of composition" of the "social". Perhaps the main tension in our thinking about what is "social" and what is "technical" results from the fact that from the very beginning we contrast the machine with life, what is technical with what is organic, the principle of mechanical repetition with the principle of spontaneity and creativity of life, just as if technology, at its source, remained on the service of the death drive, and social life and communication relations remained on the services of free action carried out beyond any limitations. Similarly, we oppose automatism and autonomy; as if automatism was the main threat to our autonomy, and as if autonomy could not rely upon automaticity and could only be annihilated by automation.

The author argues that we need a new concept of "technology", such that would not be conflicted with the concept of "life" and, likewise, a concept of "life" that would not be detached from the concept of "technology". We must see the "technical" elements within life itself and see the "organic" and "socialization" within the technical. The author also argues that we should seriously consider the hypothesis, according to which, the prime area of expression of human inventiveness is not the production of external tools, but above all the reorganization of the functions of the body organs. It was Lewis Mumford who in the first volume of The Myth of the Machine suggested that the primary task of man is to create tools for "self-control" and the control of "internal excess", "explosive nature of the brain”, or "internal anxiety" (Mumford, 1967). Socialization tools, such as customs, rituals, words, commands, organization overtook tools understood as instruments of work and giving effect on the world's matter. If "mechanization of people" was a phenomenon earlier than "mechanization of working tools", we should rethink the category of "socialization" and the category of "machine". We should also revise our thinking about autonomy and automatism, perhaps returning to the Hegelian definition of the machine as an "independent (automated) tool".

The ultimate purpose of this text, though only outlined here, is to think about the enigmatic concept of "techno-utopia”, i.e., to look for its new, more awaited, and less obvious meaning. The term "techno-utopia” is a strange fusion of utopia and technology. We do not know whether the dominant side is utopia or technology. We would like the meaning of this term to be determined not by a "struggle" but by the kind of "reconciliation", amalgam, i.e., the creation of a "third meaning" in which "technology" would be socialized from the very beginning, and that which is "social" would be already technicalized at the time of conception of the so-called "social fact". Techno-utopia is a "new place" for a utopia; it is a "different place", or the "real place" of utopia, but also a "different technology" of producing the social. As part of the techno-utopia, what is social would not brutally eliminate what is non-social, what is not living, or that what is only material. This is the hope 
permeating this text. That is also why one of the titles of this text could be a paraphrasing of the famous Heidegger text and the ensuing question concerning techno-utopia.

\section{The Very Concept of Technology}

Let us start with the concept of technology. We usually think of technology as a set of devices used to implement and optimize a certain goal. That is why we distinguish its different technologies and never see technology itself; we recognize military technics, communication technics, construction technics, educational technics, locomotion technics, or information technology. When, in the spirit of the Frankfurt School, we criticize instrumental reason, we also acknowledge that technology is nothing but instrumental reason. This instrumental reason is most often contrasted with communication or aesthetic reason. Remaining a prisoner of this rhetoric, Habermas posits, for example, that technics stands for, on the one hand, a set of measures that enable effective implementation of goals, on the other hand, a system of rules defining purposeful-rational action (Habermas, 1974). Technics are, therefore, tools, machines, and devices that optimize and rationalize the work process, but also strategies and technologies, i.e., the rules of rational choice, instrumental rules, which set out the procedures for reaching specific goals. Habermas finds technology both at the level of management, as well as at the level of executing the action. Technology governs by technical regulations. Technics is in regard to only purely technical questions. The key threshold in this narrative is the moment when technical means become „technologies”, i.e., the moment when "tools” are no longer vainly mobilized to a single case, but remain available for repetitive use.

One important consequence of this way of thinking is in the explicit suggestion that since political domination has taken the form of technical regulation, it cannot be abolished without removing technics itself. "Freedom from technology" becomes here a synonym of "freedom in general" and "all freedom". In this approach, "pre-technological man" is untamed and unspoiled, a man not reduced to the role of a servant (subject) merely servicing the instruments of work. The author argues that this fantasy about the existence of a pre-technological or post-technological man is a fantasy that has dominated the literary, philosophical, and cinematographic imagination of the West. From Jean-Jacques Rousseau's Julie, or the New Heloise to Theodor W. Adorno and Max Horkheimer's Dialectic of Enlightenment; from Frankenstein or The Modern Prometheus by Mary Shelley or The War of the Worlds by Herbert George Wells to Summa Technologiae and The Cyberiad by Stanisław Lem and Do Androids Dream of Electric Sheep? by Philip K. Dick; from All Around the Moon by Jules Verne to Looking Backward by Edward Bellamy; and from Fritz Lang's Metropolis (1927) to Ridley Scott's Alien Series (1979-2017), humanity lives in a growing fear of technology and with a declining hope for freedom from technology (Rousseau, 1761/1997; Adorno \& Horkheimer, 1944/2002; Shelley, 1818/2008; Wells, 1897/1993; Verne, 1870/2014; Bellamy 1888/1960; Lem, 1964/2013; Lem, 1965/1975; Dick, 1968). Social Utopia becomes an island not yet infected with high technologies resulting in permanent supervision, universal mobilization, and destructive conformism.

There is also another utopian narrative. There is a happy story about technology that mastered nature for human purposes. Charles Fourier, one of the authors of this narrative, deeply believed that if his ideas were implemented, sea water would turn into lemonade and whales would be happily hauling ships. According to Fourier, owing to well-organized social work, four moons would light up the earth's night, polar ice caps would melt, seawater would get desalinated, and predatory animals would commit to the service for humans (Fourier 1816/1971). All this illustrates the type of work that, far from exploiting nature, would release from its womb a 
dormant opportunity. Is the naivety of such ideas not the result of dissolving utopia in technology? After all, Herbert George Wells' time machine does not bring us to a politically-thought-out organization, benefiting everyone, but a sluggish race living in small groups and feeding on fruits. It is a humanity liberated from both work and thinking, humanity at its end, humanity unemployed.

If technology expropriates man from "work" as the only sensible human activity, does the same work define "humanity"? If technology evicts man "from memory" and if it drives man "into oblivion" and "the tyranny of newness", does memory constitute "humanity”? If technology automates, i.e., allows to go from autonomy to automation, from the epoch of tools to the era of machines, does it deprive man of the autonomy, i.e., leading man from automation to autonomy, or does it redeem and redefine it-finding autonomy in automatics? If technology offers time to man, filling man's time with its work, does it allow man to be "out of time” or that man can forget about the finiteness of man's time? Does technology serve as a tool for expanding or cancelling time, or does it give us only the illusion of "time management", no more the time of work, but of its finite life? Is utopia, in searching for a place for a man without work, without time, or without memory a utopia constantly subject to technological fear or rather the anticipation of the present future?

The author argues that, despite many intellectual efforts, we constantly think of "technology" as if we belonged to the age of "innocence of technology" and as if the "age of innocence of technology" ever existed. The problematic nature of the term "innocence" lies in the fact that reproduction of the human race is subject to the requirements of instrumental action or deliberate, rational action. Therefore, as long as humankind retains its biological characteristics, only the reach of the power of technical regulation is subject to historical changes, but not its structure or essence. This is an important observation. In fact, what may prove to be essential is cloning technology and entering the post-sexual era in which people no longer reproduce by engaging in more or less accidental sexual relations, but follow a "rational decision" on procreation, realized, legitimized, and controlled by biotechnological engineering.

What does all this mean? Well, it means that one should question "innocence", i.e., "neutrality of technology" and ask if it is indeed just a means to achieve the set goal, including procreation, namely, is technology really a device or an instrument remaining on human services? One should also ask if technology is a human act. Reproduction technics making man only a reproductive material in the process of the evolution of humanity perhaps relieves man from one important function, e.g., sexual function, but it entails a dismissal of such a disburdened man from his original position. One should also ask: Does the whole of technical devices constitute technology at all?

Allow the author to say straight away that Martin Heidegger replies in negative to all of the above questions, and in doing so, Heidegger occupies a privileged position in thinking about technology. For Heidegger, technology is not merely a means. Technology is a way of discovering. Heidegger, despite his explicit declaration that "[t]here is no demonry of technology, but rather there is the mystery of its essence", is equally vocal about technology being "the destiny of our era" and that "technical madness" is that technics "will eventually manage everything" and that it will disburden "man" (Heidegger, 1953/1977). How is it that technics become a way to manage everything and to disburden "man"?

For Heidegger, technology is a domain of unconcealment, i.e., truth (Wahr-heit), and not simple causality nor a matter of control over it. Heidegger asks a straightforward question: What does technology demand from nature? Does it demand that nature constantly discovers new resources of energy and matter concealed in its entrails? Is the earth, from the point of view of technology, something other than a resource of matter and 
energy, intended for further use? What does technology do to the world? Well, it "sets" nature, though it does not run its "setup". Having said that, what does it mean to "set someone or something"? What does it mean to "set nature"? How can nature be set at all?

What this "setting" means is, above all, that technology "calls" nature in a manner that a superior calls on the subordinate to provide the report. Technology is just about this "calling and reporting". It is, in a sense, the rhetoric of evocation. Technology "sets the air" so that it releases nitrogen; it "sets the earth" to release ore, uranium from ore, and, in the end, to release atomic energy from uranium. "Nature set" and "nature called" by technics becomes a "standing reserve" (Bestand). This "reserve" conveys meaning of a "setting" as well as "enframing” and thus signifies a way of discovering nature. However, Heidegger surprisingly and mysteriously adds that the essence of technology is by no means anything technological. What, therefore, is "enframing" if it is "anything technological"? Is technology a concealed, hushed up and obscure politics? Is technology a rhetoric understood as politics?

To put it bluntly, the message Heidegger conveys, is that technology is never an instrument or a mere tool. Does that mean that technologies mediate action? No, because we have ourselves become instruments for no other end than instrumentality itself. Man is possessed by technology, and it is a complete illusion to believe that we can master it (Heidegger, 1953/1977). We are framed by Gestell, which is one way in which the Being is unveiled. Is technology inferior to science and pure knowledge? No, because, for Heidegger, far from serving as applied science, technology dominates all, even the purely theoretical sciences. By rationalizing and stockpiling nature, science plays into the hands of technology, whose sole end is to rationalize and stockpile nature without end. Our modem destiny - technology—appears to Heidegger radically different from poesis, the kind of "making" that ancient craftsmen knew how to achieve. Technology is a unique, insuperable, omnipresent, and superior Force.

For a change, let us now try to trivialize Heidegger's thought a little and disenchant it. Bruno Latour, with his plebeian reading of Heidegger, gives us succour in this regard when he comes to an interesting conclusion that technology is simply "solidified work". "Technology—says Latour-is properly referred to not with a noun, but with an adjective” (Latour, 1999). For Latour, "technologies” do not exist as such; moreover, there is nothing we can define as a "technological object" or "technological gadget". There is only the adjective "technological" that we can use in many different situations. So what does the word "technological" mean in the absence of the "technology" itself?

The word "technological" can mean primarily the "program of action”, but also a certain "necessary skill” to carry out this program. Finally, the word can signify "organization of the action", as well as "a set organized around a chain of command". This is why Mumford in The Myth of the Machine boldly says that the machine takes shape when language and communication-that is, intangible work and cooperation-become the dominant production force. Latour only draws conclusions from this, when he makes a surprising point: "Boeing-747s do not fly, airlines fly" (Latour, 1999).The airlines are super-machines organizing action programs. Airlines are "technologies" if we are still willing to use this flimsy term. So what are we to deduce from the withdrawal of thought from the great dichotomy between society and technology? In what sense that what is social is the result of the action of a technical element, and in what is technical is only solidified work?

Perhaps for all these reasons, Sherry Turkle (2011) claimed that technology is seductive and proposes itself as the architect of our intimacies. From the perspective of the "inner history of technology", the computer is an evocative object that fostered new reflection about the self (Turkle, 2011). The intimate ethnography 
traced the subjective side of personal computers-not what computers do for us but what they do to us, to our ways of thinking about ourselves, our sense of being human. In the digital age, computers no longer wait for humans to project meaning onto them. Now, sociable robots meet our gaze, speak to us, and learn to recognize us. This is, what we sometimes call, a "robotic moment" (Kurzweil, 2005). However, Turkle (2011) wrote from the perspective of fear of technology.

Technology presents itself as a one-way street; we are likely to dismiss discontents about its direction because we read them as growing out of nostalgia or a Luddite impulse or as simply in vain. But when we ask what we "miss," we may discover what we care about, what we believe to be worth protecting. We prepare ourselves not necessarily to reject technology but to shape it in ways that honor what we hold dear. (p. 19)

Turkle reminds us that in The Republic, Plato says: "[...] everything that deceives seems to bewitch" (Plato, 1991, p. 92). Sociable technology will always disappoint because it promises what it cannot deliver. It promises friendship but can only deliver performances. From the very beginning, networked technologies designed to share practical information were taken up as technologies of relationship (Turkle, 2011, p. 157). Turkle (2011) drew a political conclusion out of her full of distrust to the social technology story. She is arguing that technology and its growth will threaten democracy, because

In democracy, perhaps we all need to begin with the assumption that everyone has something to hide, a zone of private action and reflection, one that must be protected no matter what our techno-enthusiasms. [...] It seems like part of democracy defining its sacred spaces. (p. 264)

Turkle asks the question: Could we, build a net that reweights privacy concerns, acknowledging that these, as much as information, are central to democratic life? The author would like to now treat this question seriously.

\section{The Very Concept of Technocracy}

In this situation, it might be necessary to rethink the very concept of technocracy. Perhaps it should not be concerned with the growth of information nor even the fears of technology, nor should it condemn nor worship it by engaging in its total criticism or its unconditional apology. Above all, it should perhaps address the question of what political form is ushered in the time of bio-techno-capitalism. Or, better yet, it should address the very consequence of merging the three terms, namely that of "time", "technique", and "democracy" ("politics"). Given the above concerns, it might be worthwhile to rethink the very concept of "technocracy" for it might render the term "technocracy" competitive towards the term "techno-utopia".

What is "technocracy"? Is it a form of government? Is it a political system? Is technocracy a political organization at all? Should technocracy be included in a number of other forms of government, such as democracy, aristocracy, monarchy, republic, or despotia? Is technocracy, in Max Weber's terminology, the "pure form" of the legal power opposing charismatic or traditional power? What is the mandate of technocracy to power? Are we living today not so much in camps, oligarchies, or democracies, as we are living in technocracies, and the modern form of digital capitalism has taken the form of imperious techno-capitalism? What is techno-capitalism doing to us? And would the fact of life in the digital age explain the key position of technology in our modern thinking?

In Book III of the Laws, Plato devotes himself to a systematic inventory of the qualifications_axiomata-for ruling, along with certain correlative qualifications for being ruled. Out of the seven he retains, four are traditional qualifications of authority based on a natural difference; that is, the 
difference in birth. Those qualified to rule are those "born before" or "born otherwise". This grounds the power of parents over children, old over young, masters over slaves, and nobles over serfs. The fifth qualification is introduced as the principal principle that summarizes all natural differences. It is the power of those with a superior nature, of the stronger over the weak-a power that has the unfortunate quality, discussed at length in the Gorgias, of being indeterminate. The sixth qualification, then, gives the only difference that counts for Plato; namely, the power of those who know over those who do not. There are thus four couplings of traditional qualifications to be had, along with two theoretical couplings that claim priority over them, namely, natural superiority and the rule of science qua knowledge (Plato, 1988).

The list ought to stop there. But there is a seventh qualification: "the choice of god", otherwise referring to a drawing of lots that designates the one who exercises arche. Plato does not expand upon this. But clearly, this kind of "choice" points ironically to the designation by God of a regime previously referred to as one only God could save: democracy. What thus characterizes a democracy is pure chance or the complete absence of qualifications for governing. Democracy is the state of exception where no oppositions can function, where there is no pre-determined principle of role allocation. Democracy is the specific situation in which there is an absence of qualifications that, in turn, becomes the qualification for the exercise of a democratic arche. What is destroyed in this logic, is the particular quality of arche, its redoubling, which means that it always precedes itself within a circle of its own disposition and its own exercise. But this exceptional state is identical with the very condition for the specificity of politics more generally.

Laws is Plato's late dialogue, in which Socrates is absent. However, Socrates is present in the dialogue entitled Republic. What does the title really mean? The Greek title of Plato's Republic is politeia and this word is ordinarily translated as "constitution". This means, not only structure as we may understand it, but also a whole way of life. We would translate politeia literally, however, as "regime" or "polity". When you speak of democracy or aristocracy as a way of life and not as a mere procedure for having a government, then democracy would be a regime in this sense. In Republic, according to Socrates, there are five kinds of regime: (1) kingdom or aristocracy, the rule of the best man or the best men, that is directed toward goodness or virtue, the regime of the just city; (2) timocracy the rule of lovers of honor or of the ambitious men which is directed toward superiority or victory; (3) oligarchy or the rule of the rich in which wealth is most highly esteemed; (4) democracy, the rule of free men in which freedom is most highly esteemed; and (5) tyranny, the rule of the completely unjust man in which unqualified and unashamed injustice holds sway (Plato, 1993).

After this digression referring to the classical political philosophy and reminding us of known and possible political systems and forms, allow the author to return to the problem of technocracy. Technocracy-understood as a political form, but also a certain form of life-is obviously not accounted for in neither the enumeration of the elders, neither in Plato's Laws, nor in the Socrates' enumeration found in Republic. One could argue that the ancient philosophers did not deal with technocracy, because they lived in the repression of technology. One might argue that technocracy is a modern invention. One could argue that mass democracy is born with technology. If that were the case, it would render yet more important the question: What form of constitution, what form of life is technocracy? What form of qualifications, competences (axiomata) does technocracy represent?

Well, the provisional answer to this question is: Technocracy, just as theocracy, both unaccounted for in the Socrates enumeration, is an inhuman form of government. Technocracy is neither the rule of best nor the most ambitious, the richest nor free people. Technocracy is not "the rule of the elderly", "parents", "teachers", 
"noble people", or even "preachers". While it may be tempting to associate technocracy with governments of "educated people”, "people who know better”, i.e., who know what means to use for given purposes, it would naively identify technocracy with meritocracy and it would constrain the concept of technology to that of a tool that the author has warned against.

Technocracy is not epistemocracy; it is not the rule of educated people. It cannot be that way, because technocracy is not at all the rule of people. Nor is it a government of Gods'. Perhaps these are the governments of cyborgs, i.e., the governments of the automated and autonomous technology itself, which becomes a kind of unbearable tyranny of inhuman rationality. Technocracy—from this point of view-is the fundamental opposite of democracy, because it eliminates the notion of fortune, fate, or chance, but it also eliminates freedom understood as the madness of choice. In a word, technocracy is something between theocracy and tyranny. Here, power comes from heavens, but not as a miracle, but as a call to a report. Technocracy, after theocracy, would inherit the apology of the inhuman order, and after tyranny-indifference to the issues of justice, a whim of infantile philosophers, like Socrates. God's law of European powers was spoken through the words of Saint Paul, who famously proclaimed that "there is no authority except from God". Not only every power comes from God, but also every God and every rule on the earth must find its justification in the power of technology or the power of ensuring order on earth. Thereby, the "automat”, “apparatus”, “dispositif”, or "installation” is what God has become. The installation brings indifference to justice and invalidates all revolution except the technical revolution.

\section{The Very Concept of Apparatus}

Giorgio Agamben, in his famous commentary on the writing of Michel Foucault titled "What is an apparatus?”, convinces us that the central yet enigmatic concept for the author of the History of Sexuality was that of "dispositive". Agamben (2009) claimed that dispositif, or "apparatus" (in English), is a decisive technical term in the strategy of Foucault's thought (pp. 1-25). Foucault (1998) introduced this concept in the first volume of The History of Sexuality, when he describes what he calls the "deployment of sexuality". Foucault (1998) wrote:

The deployment of alliance has as one of its chief objectives to reproduce the interplay of relations and maintain the law that governs them; the deployment of sexuality, on the other hand, engenders a continual extension of areas and forms of control. (p. 75)

Foucault adds: The deployment of sexuality has its reason for being, not in reproducing itself, but in proliferating, innovating, annexing, creating, and penetrating bodies in an increasingly detailed way, and in controlling populations in an increasingly comprehensive way.

Without going into a polemic with Agamben whether or not he is accurate in his diagnoses of a political and intellectual stake in Foucault's philosophy, the author would like to take a moment of reflection on the key concept of dispositif (apparatus) in the context of our previous analyses of the term "technology". In what sense "dispositif" ("apparatus") differs from the concept of "technology”, especially in the Heideggerian sense of the term?

What Heidegger called Gestell is at first glance similar, from an etymological point of view, to dispositio, disponere, just as the German stelen corresponds to the Latin ponere. Comparing technology with "dispositif", one should ask: What does it mean to be at someone's disposal? In what sense does the word "dispositif" 
constantly contain in itself memory in dispositional meaning? Finally, one should ask if freedom available here on earth is only about being not "disposed by" or not "at the disposal" of any deviceor master? Nature-in Heidegger-constantly evoked by technology, remains "at the disposal" or is even placed "to the disposition" of unknown powers. Hence, it is in the status of a setting, enframing, or stock. Who is at whose disposal here? Who disposes whom?

In answering these questions, let us start by saying that Agamben's analyses circulate around the concept of dispositif following three directions. Reading Foucault's statements from various years, Agamben concludes that the term "apparatus" in the work of the author of A History of Insanity in the Age of Reason essentially means three things: (1) a heterogeneous set that includes virtually anything, linguistic and non-linguistic units, discourses, institutions, buildings, laws, police measures, philosophical propositions, and so on; (2) a set of strategies of the relations of forces supporting, and supported by, certain types of knowledge; and (3) the specific historical relation between individuals as living beings and the set of institutions, of processes of subjectification and of rules in which power relations become concrete.

After further etymological investigation, Agamben comes to the final semantic conclusion and claims that if we try to examine the definition of "apparatus" that can be found in common French dictionaries, we see that these books distinguish between three meanings of the term. What are those three meanings? Well, first of all, we find, and in a strictly juridical sense: Apparatus is the part of a judgment that contains the decision separate from the opinion; that is the section of a sentence that decides or the enacting clause of a law. Second, a technological meaning: the way in which the parts of a machine or of a mechanism are arranged. Finally, third, we encounter a military use: the set of means arranged in conformity with a plan. Agamben, in a somewhat less conclusive tone, adds that to some extent, the three definitions are all present in Foucault.

After this semantic differentiation, let us ask the question: What is this original meaning for the term "apparatus"? How do meanings of the term "apparatus"-that of a judgment, mobilization of resources, and strategy of action-intertwine with each other? As a working hypothesis, let us try this answer: The term certainly refers to a set of practices and mechanisms-both linguistic and non-linguistic, juridical, technical, and military-that aim to face an urgent need and to obtain an effect that is more or less immediate. But what does it mean to use all the above means in a situation of imminent need? Well, it seems to me that the term dispositif means nothing else but a kind of "crisis management" or a series of answers to the "crisis situation". The term dispositive means simply a certain composition of forces, the mobilization of all available material and immaterial resources, all available powers of action, in order to create a "setting" capable of working together and capable of dealing with the crisis. But what is the crisis that will give rise to the announcement of a permanent state of emergency which is probably never-ending? In what sense does the crisis allow us to announce the state of mobilization in which humanity must remain at its disposal, just as nature, waiting for the verdict in its case?

\section{Closing Remarks}

Well, the answer to this last question is quite twisted. The author is saying that the state of emergency is announced when humanity is concerned about the disappearance of "humanity". Nothing concerns humanity more than the fact and the possibility of its disappearing. Technics, automation, cybernetics, and simulated intelligence disturb humanity not only by their invasiveness, but above all, by the fact that they create the possibility of another intelligence, another policy, another organization, a different composition, and another 
democracy. Humanity wishes to ensure its purity and purity of its key concepts. Technology creates a threat of "unclean species", non-human elements. Technology evokes the fantasy of subjecting and capturing in humanity, and it is not surprising since the same humanity, from the beginning, from Prometheus, must find in technology the source of its strength and the moment of its birth, i.e., technology of subjectification and subjectivization power. What does this last ambivalence mean?

It means that a techno-logical being is permanently and irreversibly pharmacological (Stiegler, 2015). The pharmacy sells medicines and poisons at the same time. Pharmacy is ambivalent by definition (Derrida, 1981, pp. 63-171). Mnemotechnics is certainly a condition and the possibility of all reason, but also the possibility and condition of all fooling. Socialization of technology has been achieved through a communication shift, because all communication and all socialization are done today "through" and "within" the socialized technology. On the other hand, the desocialization of the world of politics has also taken place through a "communication shift" in new media, because all politics is going "through" the media today and is "in the media”, i.e., still "unsocialized technology”. Every technology implies a process of subjectification, without which it cannot function as a technology of governance, but is rather reduced to a mere exercise of violence. Technology, then, is first of all, a machine that produces subjectifications, and only as such is it also a machine of governance. What technology that we have to deal with in the current phase of capitalism is that they no longer act as much through the production of a subject, as through the processes of what can be called desubjectification.

The foundation of the age of machine is not the industrial revolution, but the creation of a machine made of people. The primitive people have very rudimentary technology and at the same time very sophisticated rites. These were not the first automatons but the pyramids which transformed the organic into the mechanical. The machines for tuning humanity are older than the machines used to expropriate humanity from the work process. The machine is primal with respect to the technical element. The technical element of the machine retains an abstract, indeterminate character, unless it refers to a certain setting, labour relations and social relations. These, however, are determined by the composition, "dispositif”, Gestell, or collective. It is, in this sense, "technology is society made durable” (Latour, 1991, pp. 1303-1327).

Finally, allow the author to make one strictly political remark. If by "technics"-following the model devised by Habermas - we continue to understand „scientifically rationalized disposal” and control over objectified processes of cognition, knowledge, experiencing the world, communication and action, that is, a system in which scientific research, coupled with economy and management, create a new form of techno-scientific domination; and by "democracy" we understand the institutional safeguards of universal and public communication about redistribution and recognition, then we will certainly have to conclude that the "liberating power of reflection" cannot be replaced by the development of "technologically useful knowledge" and that technology is a bad poison for democracy. However, there is another way to think about technology and democracy.

We can assume-following Stiegler's formula—that the duplication of audiovisual objects alongside the access to production tools, will allow the emergence of new forms of knowledge and new forms of power (Stiegler, 2009, pp. 40-59). The alphabetical record of speech, just like the audiovisual registration of lifestyles, is associated with the process of grammatization. Gramatization enables the discretization and reproduction of flows through which individuals and groups of individuals individualize, i.e., become who they are. If audiovisual media shorten communication circuits and invalidate diacritism, they become a threat to democracy, 
and if they strengthen diacritism and allow for an extension of communication circuits, they give an opportunity for new techno-cultural isonomy. Perhaps one can think of an analogy between the advent of an era of alphabetical writing discretizing speech flows and the advent of the age of digital media discretising audiovisual objects. Discretization, or the process of transforming continuous models into their discrete counterparts, must be associated with the process of literalization and literatureization of societies. The death of grammar would be the death of democracy.

Central to this text, though not fully disclosed, the notion of techno-utopia would thus gain rather surprising meaning. It would not at all praise technology nor praise the power of productive means as a progressive force of humanity. On the contrary, the term "techno-utopia" would mean not so much a "utopia of technology" or even a "technology of utopia", i.e., a technology to create a better place, a place for another community, and another democracy, possibly tele-democracy and techno-democracy, which would be effected "on-screen" and "through the screen" in order to go "beyond the screen". It should be added, however, that the "screen" is gains here, as it is in Jacques Derrida, spectral character (Derrida, 1994). We may guess that "democracy of the future", "the coming community", just as it is the case with "television of the future" or "internet of the future", or "technology of the future", will not be based on "screen" and that it will display images, sometimes synthetic, directly on the surface of the eye-analogous to the sound of the phone, detected deep in the ear. Karl Marx is one of the few thinkers of the past who seriously considered the sourcing inseparability of technology and language, technology and politics, i.e., tele-technology, tele-politics, tele-democracy, and tele-utopia, bearing in mind that every language is in fact a tele-technology.

Perhaps the term of techno-utopia is not a holistic fusion of utopia and technology, but rather radical transversal relations that generate new modes of subjectivity. The merger of the human with the technological results in a new transversal compound, a new kind of techno-utopia pact or covenant not unlike the relationship between the animal and its planetary habitat.

\section{References}

Adorno, W. T., \& Horkheimer, M. (1944/2002). Dialectic of enlightenment. (E. Jephcott, Trans.). Stanford: Stanford University Press.

Agamben, G. (Ed.). (2009). What is an apparatus? In "What is an apparatus?” and other essays (D. Kishik and S. Pedatella, Trans.). Stanford: Stanford University Press.

Bellamy, E. (1888/1960). Looking backward 2000-1887.'Boston, Massachusetts: Houghton Mifflin Company.

Derrida, J. (1994). Specters of Marx: The state of the debt, the work of mourning and the new international. (P. Kamuf, Trans.). New York: Routledge.

Derrida, J. (Ed.). (1981). Plato’s pharmacy. In Dissemination (pp. 63-171, B. Johnson, Trans.). Chicago, University of Chicago Press.

Dick, P. K. (1968). Do Androids dream of electric sheep? New York: Doubleday and Company Inc.

Foucault, M. (1998). The history of sexuality: The will to knowledge (Vol. 1, R. Hurley, Trans.). London: Penguin.

Fourier, C. (1816/1971). Design for Utopia: Selected writings. New York: Schocken.

Habermas, J. (Ed.). (1974). Dogmatism, reason, and decision: On theory and praxis in our scientific civilization. (J. Viertel, Trans.). In Theory and practice. Boston: Beacon Press.

Heidegger, M. (1953/1977). “The question concerning technology” and other essays. (W. Lovitt, Trans.). New York, NY: Harper and Row.

Kurzweil, R. (2005). The singularity is near: When humans transcend biology. New York: Viking Penguin.

Latour, B. (1991). Technology is society made durable. In J. Law (Ed.), A sociology of monsters essays on power, technology and domination: Sociological review monograph (pp. 1303-1327). New York: Routledge.

Latour, B. (1999). Pandora's hope: Essays on the reality of science studies. Cambridge, Mass.: Harvard University Press. 
Lem S. (1965/1975). The cyberiad_Fables for the cybernetic age. (M. Kandel, Trans.). United Kingdom: Secker \& Warburg. Lem, S. (1964/2013).Summa Technologiae. (J. Żylinska, Trans.). Minneapolis: University of Minnesota Press.

More, T. (1516/1967). Utopia. (J. P. Dolan, Trans.). In J. J. Greene and J. P. Dolan (Eds.), The essential Thomas more. New York: New American Library.

Mumford, L. (1967). The myth of the machine: Technics and human development (Vol. 1). New York: Harcourt, Brace \& World. Plato. (1988). The laws. (T. L. Pangle, Trans.). Chicago: University of Chicago Press.

Plato. (1991). The republic of Plato. (A. Bloom, Trans.). New York: Basic Books.

Plato. (1993). Symposium. (A. Bloom and S. Benardete, Trans.). Chicago: University of Chicago Press.

Rousseau, J. J. (1761/1997). Julie, or, the new Heloise: letters of two lovers who live in a small town at the foot of the alps. (P. Stewart and J. Vaché, Trans.). Hanover, N.H.: University Press of New England.

Shelley, M. (with Shelley, P.) (1818/2008). The original Frankenstein. (C. E. Robinson, Ed.). Oxford: Bodleian Library.

Stiegler, B. (2009). The carnival of the new screen: From hegemony to isonomy. In P. Snickars and P. Vonderau (Eds.), The YouTube reader (pp. 40-59). Stockholm: National Library of Sweden.

Stiegler, B. (2015). States of shock: Stupidity and knowledge in the twenty-first century. (D. Ross, Trans.). Cambridge: Polity Press.

Turkle, S. (2011). Alone together: Why we expect more from technology and less from each other. New York: Basic Books.

Verne, J. (1870/2014). All around the moon/space novels. (E. Roth, Trans.). BookRix.

Wells, H. G. (1897/1993). A critical edition of the war of the worlds: H.G. Wells's scientific romance. (D. Y. Hughes and H. M. Geduld, Eds.). Bloomington and Indianapolis: Indiana University Press. 